\title{
PENGEMBANGAN PARIWISATA HALAL DI INDONESIA TINJAUAN ETIKA BISNIS ISLAM
}

\author{
Alvien Septian Haerisma \\ Mahasiswa Pascasarjana Program Doktor \\ Universitas Islam Negeri Sunan KalijagaYogyakarta \\ e-mail:alvienseptian@gmail.com
}

\begin{abstract}
Halal industry becomes a global trend and business opportunities in various countries. Halal industry brings benefits to the Indonesian economy in terms of products. The scope of the halal industry in the midst of today's global economy includes several aspects: Financial services industry, food and beverage industry, pharmaceutical and pharmaceutical industry, cosmetic beauty industry, hospitals and tourism industry, and fashion and lifestyle industries. Halal tourism market becomes the future of a nation's economic resources. The demand for world halal tourism shows positive growth so that all countries in the world must prepare their infrastructure and become business opportunity as foreign exchange of the country. Economic activity is time to incorporate ethical values in various business branches. There are five key axioms governing Islamic business ethics in it consisting of unity, balance and equilibrium, free will, and responsibility and benevolence. Islamic business ethics in the development of halal tourism in Indonesia has been done by the government, businessmen or managers of tourism or the wider community as consumers and other stakeholders.
\end{abstract}

Keywords: Halal Industry, Halal Tourism, and Islamic Business Ethics.

\begin{abstract}
Abstrak
Industri halal menjadi tren global dan peluang bisnis diberbagai negara. Industri halal membawa kemanfaatan bagi perekonomian Indonesia dilihat dari sisi produk. Ruang lingkup industri halal di tengah perekonomian global saat ini mencangkup beberapa aspek, diantaranya: Industri pelayanan keuangan, industri makanan dan minuman, industri farmasi dan obat-obatan, industri kecantikan kosmetik, industri rumah sakit dan pariwisata, dan industri fashion dan lifestyles. Pasar pariwisata halal menjadi masa depan sumber ekonomi suatu bangsa. Permintaan pariwisata halal dunia menunjukkan pertumbuhan positif sehingga seluruh negara belahan dunia harus menyiapkan infrastrukturnya dan menjadi peluang bisnis sebagai devisa negara tersebut. Aktivitas ekonomi sudah saatnya untuk memasukkan nilainilai etik diberbagai cabang bisnis. Terdapat lima aksioma kunci mengatur etika bisnis Islami didalamnya terdiri: kesatuan (unity), keseimbangan dan kesejajaran (equilibrium), kehendak bebas (free will), dan tanggungjawab (responsibility) dan kebajikan (benevolence). Etika bisnis Islam dalam pengembangan pariwisata halal di Indonesia sudah dilakukan oleh pemerintah, pengusaha atau pengelola pariwisata atau juga masyarakat luas sebagai konsumen dan stakeholder lainnya.
\end{abstract}

Kata Kunci: Industri Halal, Pariwisata Halal, dan Etika Bisnis Islam. 


\section{PENDAHULUAN}

Industri halal menjadi tren global dan peluang bisnis diberbagai negara. Halal menjadi pasar bukan saja negara mayoritas muslim bahkan negara yang minoritaspun menjadi peluang pasar yang menjanjikan. Masyarakat internasional sudah memahami istilah halal yang memiliki nilai tambah suatu produk tertentu, di mana ini dapat dijadikan gaya hidup (lifestyle) saat ini.

Industri halal membawa

kemanfaatan bagi perekonomian Indonesia dilihat dari sisi produk yaitu di antaranya; 1 ) memberikan nilai tambah yang cukup besar, 2) meningkatnya permintaan akan produk yang berbeda, industri halal menghasilkan berbagai produk halal, 3) diversifikasi persediaan dan kompetisi yang semakin ketat, namun pasar halal relatif mudah dan semarak, 4) Inovasi cemerlang ditandai oleh dinamika pasar halal mendorong semua produsen di industri halal untuk berinovasi karena dinamika pasar halal, dan 5) Meningkatkan standar kualitas dengan label halal sebagai simbol universal kualitas dan kegunaan yang baik. ${ }^{1}$

Ruang lingkup industri halal di tengah perekonomian global saat ini mencangkup beberapa aspek, di antaranya: Industri pelayanan keuangan, industri makanan dan minuman, industri farmasi dan obat-obatan, industri kecantikan kosmetik, industri rumah sakit dan pariwisata, dan industri fashion dan lifestyles.

Beberapa contoh cabang dari pariwisata di masa kini, merujuk pada fatwa-fatwa ayatullah al'udzma Sayyid 'Ali al-Ḥusaeni Assistāni, diantaranya sebagai berikut ${ }^{2}$ : pariwisata ilmu dan budaya, pariwisata religi / syari'ah, pariwisata obat / penyembuhan / kesehatan, pariwisata alam, pariwisata perdagangan, pariwisata jasmani.

\footnotetext{
${ }^{1}$ Akhmad Akbar Susamto, Halal Industry as a New Source of Economic Growth (Jakarta: The International Seminar Seizing Golden Opportunity of Global Halal Business, 2017), 11-15.

${ }^{2}$ Sayyid Muhammad al-Ṣākhin (ed), Fiqhul Siyāhah wa Safar, cet.1 (Beirūit: Dār al-'Auliyâ', 2008), 9.
}

Pasar pariwisata menjadi masa depan sumber ekonomi suatu bangsa. Permintaan pariwisata halal dunia menunjukkan pertumbuhan positif kedatangan wisatawan internasional. meningkatnya permintaan dimulai dari tahun 1950 sampai 2007 menunjukkan peningkatan pesat perjalanan internasional selama tahun-tahun awal pasca perang. ${ }^{3}$

Keberadaan industri pariwisata halal bukanlah suatu ancaman bagi industri pariwisata yang sudah ada, melainkan sebagai pelengkap khususnya bagi wisatawan muslim dan semuanya itu tidak menghambat kemajuan usaha wisata yang sudah berjalan. Bahkan sejumlah negara di dunia telah menggarap industri pariwisata halal.

Dalam studi Mastercard-Crescent Rating Global Muslim Travel Index (GMTI) pada 2016, disebutkan bahwa total jumlah wisatawan muslim dunia mencapai 117 juta pada 2015. Jumlah itu diperkirakan terus bertambah hingga mencapai 168 juta wisatawan pada 2020 dengan pengeluaran di atas 200 miliar dollar AS atau sekitar Rp 2,6 triliun. Potensi pariwisata halal sendiri diperkirakan akan terus tumbuh. Prediksi pada tahun 2020, jumlah wisatawan akan tumbuh menjadi 156 juta turis dengan pengeluaran mencapai 220 miliar dollar $\mathrm{AS}^{4}$

Pariwisata halal menggambarkan pergerakan dari waktu ke waktu dibandingkan beberapa dari industri halal lainnya, sebagai berikut: tumbuh $100 \%$ lebih cepat daripada sektor pariwisata lainnya, mencapai \$ 135 miliar nilai pemesanan perjalanan ke luar negeri (outbound), diprediksi akan tumbuh hingga

\footnotetext{
${ }^{3}$ Wan Sahida Wan Zulkifli, S.A Rahman, K.W. Awang and Y.B. Che Man, "Developing the Framework for Halal Friendly Tourism in Malaysia," Medwell Journals: International Business Management 5, No. 6 (2011): 295-302.

${ }^{4}$ Wahyu Adityo Prodjo, "Cara Indonesia Menjadi Destinasi Wisata Halal Terbaik di Indonesia", Kompas.com. Diakses pada tanggal 04 Oktober 2018.
} 
\$200 miliar pada tahun 2020 dan akan menjadi sebuah generator besar bisnis langsung dan jangka panjang dengan pendapatan maksimum. ${ }^{5}$

Faktanya kondisi pariwisata halal di Indonesia masih belum maksimal, padahal potensi geografi Indonesia terbentang luas, tidak hanya terbatas pada 3 propinsi yaitu Nusa Tenggara Barat (NTB), Sumatera Barat dan Aceh sebagai destinasi pariwisata halal yang telah ditetapkan. Hal inilah nampaknya dapat menghambat untuk melakukan percepatan dalam pengembangan pariwisata halal secara menyeluruh.

Penerapan pariwisata halal masih menghadapi kendala-kendala teknis. Salah satunya aspek sertifikasi produk-produk halal. Di Indonesia, restoran dan kafe sebagai penunjang pariwisata halal masih baru dalam tataran self claim, belum bersertifikat. Jumlah hotel dan restoran yang menjamin makanannya halal masih jarang. Masalah tempat ibadah dan air menjadi luput bagi pengusaha wisata halal ini, terutama di hotel dan pusat perbelanjaan mewah.

Para pelaku usaha industri halal khusunya bidang pariwisata dituntut mempunyai kesadaran mengenai etika dan moral dalam berbisnis, karena keduanya merupakan kebutuhan dalam menghadapi tuntutan global. Pelaku usaha atau perusahaan yang ceroboh dan tidak menjaga etika, tidak akan berbisnis secara baik sehingga dapat mengancam hubungan sosial dan merugikan konsumen, bahkan dirinya sendiri. Nilai-nilai etik yang membuat aktivitas ekonomi dapat berhasil dengan baik, tidak hanya bertujuan meraih nilai materi (duniawi) namun juga bertujuan ukhrawi. Inilah nilai-nilai etik yang membuat manusia bahagia baik di dunia dan

\footnotetext{
${ }^{5}$ Ministry of Tourism Indonesia, Indonesia dominates world halal tourism awards 2016 winning 12 top categories, dalam http://www.indonesia.travel. Diakses pada tanggal 14 Oktober 2018.
}

akhirat. Ketika kegiatan ekonomi yang dijalankan hanya semata-mata untuk meraih nilai-nilai materi saja, pada akhirnya yang terjadi adalah kerusakan di mana-mana.

Bisnis menggunakan etika merupakan sebagai sentral bahwa agama senantiasa menjadi kekuatan yang besar untuk menyatukan manusia di dalam komunitas moral, memotivasi menuju perilaku konstruktif dan manusiawi dan bagi penekanan aspek universal ketimbang partikularitas eksistensi umat manusia ${ }^{6}$. Hal ini menjadi perhatian khususnya para pengusaha untuk senantiasa melakukan dan mengimplementasikan wisata halal sesuai dengan ketentuan undang-undang yang berkaitan dengan kepariwisataan dan beberapa peraturan pemerintah tentang rencana induk pembangunan pariwisataan nasional.

Oleh karenanya pada tulisan ini memfokuskan pada pertanyaan, bagaimana analisis etika bisnis Islam dalam pengembangan pariwisata halal di Indonesia? Studi ini disusun untuk memaparkan konsepsi pariwisata halal dari peraturan yang ada di Indonesia dan juga dari pendapat tokoh dan akhirnya mencoba melihat sejauhmana pengembangan pariwisata halal di Indonesia. Akhirnya dalam paper ini mencoba memfokuskan dan menganalisis etika bisnis Islam dalam pengembangan pariwisata halal di Indonesia, guna untuk memberikan kontribusi akademik untuk masa depan Indonesia khususnya di bidang pariwisata halal.

\section{LITERATURE REVIEW}

Penelitian tentang pengembangan pariwisata halal di Indonesia bukanlah suatu yang baru. Meskipun demikian, nampaknya belum ditemukan penelitian yang secara spesifik yang ditininjau dari etika bisnis Islam. Berikut beberapa karya yang

${ }^{6}$ Sohail H. Hashmi (Ed), Etika Politik Islam: Civil Society, Pluralisme, dan Konflik, (Jakarta: ICIP, 2005), 234-235. 
terdokumentasikan terkait permasalahan yang dikaji, yaitu pertama, Izza Firdausi, et.al. dalam "Lombok: Halal Tourism as a New Indonesia Tourism Strategy". Dalam paper tersebut dinyatakan bahwa sejak tahun 2012 sampai sekarang, pemerintah Indonesia bermaksud untuk memperkenalkan 12 destinasi pariwisata halal di Indonesia. Destinasi tersebut adalah Aceh, Barat Sumatera, Riau, Lampung, Banten, Jakarta, Jawa Barat, Jawa timur, Jawa Tengah, Yogyakarta, Nusa Tenggara Barat dan Sulawesi Selatan. Kebijakan pemerintah menyadari bahwa ada peluang bisnis baru pariwisata yang disebut pariwisata halal atau pariwisata syariah yang menarik banyak turis asing dari negara berpenduduk muslim tersebut seperti Arab Saudi, Brunei Darussalam, Mesir, dan banyak lagi. ${ }^{7}$

Kedua, Tazbir Abdullah dalam penelitiannya "Memanfaatkan Momentum Tren Pariwisata Halal". Menurut Tazbir negara yang terbentang luas terdiri pulau, lautan dan samudra, Indonesia dinilai cukup strategis dalam perkembangan pariwisata halal. Indonesia saat ini memiliki tiga propinsi yang strategis dan besar mampu melayani lebih dari 1,8 miliar penduduk muslim dunia. Ini menjadi destinasi model pariwisata halal di Indonesia yakni Nusa Tenggara Barat (NTB), Sumatera Barat dan Aceh. Selain propinsi di atas, pemerintah juga mendorong daerah lain untuk menjadikan pariwisata halal sebagai nilai tambah sektor pariwisata daerah. ${ }^{8}$

Ketiga, Aan Jaelani dalam "Halal Tourism Industry in Indonesia: Potential and Prospects", yang dinyatakan bahwa pengembangan pariwisata halal adalah bagian menarik bagi industri halal di

${ }^{7}$ Izza Firdausi, et.al., "Lombok: Halal Tourism as a New Indonesia Tourism Strategy". Paper presented at 4th International Conference on Humanities, Social Sciences and Education" (Dubai: ttp., 2017), 53-56.

${ }^{8}$ Tazbir Abdullah, "Memanfaatkan Momentum Tren Pariwisata Halal", Halal lifestyle dan Business, Vol. 09 (2017): 34-37.
Indonesia seiring dengan tren halal lifestyle dalam aspek gaya hidup keseluruhannya. Dinamika pariwisata dunia dalam tiga tahun terakhir dipengaruhi oleh peningkatan jumlah perjalanan antar negara dan pertumbuhan perekonomian terutama di kawasan Asia Pasifik. Indonesia sebagai negara yang memiliki keragaman budaya (culture) dan agama (religion) yang terdiri suku, etnis, bahasa, dan adat kebiasaan menjadi potensi dalam pengembangan pariwisata. Secara khusus, umat Islam sebagai mayoritas masyarakat di Indonesia tentunya memiliki keunikan yang menjadi ciri khas bangsa dengan destinasi pariwisata yang ada. ${ }^{9}$

Dari ketiga penelitian yang telah dipaparkan di atas, secara khusus peneliti tersebut memiliki perbedaan dengan permasalahan dalam penilitian ini. Perbedaan yang paling jelas di sini adalah pemilihan tinjauan dari segi etika bisnis Islam dalam pengembangan pariwisata halal di Indonesia. Hal inilah letak perbedaan studi ini dengan studi-studi yang telah dilakukan sebelumnya.

\section{METODOLOGI PENELITIAN}

Jenis penelitian yang digunakan adalah penelitian kepustakaan. Penelitian kepustakaan merupakan penelitian yang penemuanya didapatkan dengan mencari data dari berbagai literatur dan referensi yang berhubungan dengan materi pembahasan. ${ }^{10}$ Oleh karena itu, penelitian tentang pengembangan pariwisata halal di Indonesia dalam penilitian ini menggunakan tinjauan etika bisnis Islam melalui metode review dokumen dan trend analysis.

Pendekatan penelitian yang dilakukan menggunakan pendekatan kualitatif normatif, yaitu sebagaimana cara

${ }^{9}$ Aan Jaelani, "Halal Tourism Industry in Indonesia: Potential and Prospects", MPRA Paper No. 76235 (Germany: University Library of Munich, 2017). Diakses 17 Oktober 2018, https://mpra.ub.unimuenchen.de/.

${ }^{10}$ Moh. Nazir, Metode Penelitian (Bandung: Ghalia Indonesia, 2003), 193. 
yang digunakan dalam penelitian hukum yang dilakukan dengan cara meneliti bahan pustaka yang ada. ${ }^{11}$

Teknik pengumpulan data merupakan langkah yang paling strategis dalam penelitian, karena tujuan utama dari penelitian adalah mendapatkan data. ${ }^{12}$ Peneliti melakukan teknik pengumpulan data dengan melakukan penelitian terhadap berbagai literatur yang dilakukan untuk mencari konsep yang ada relevansinya dengan topik pembahasan melalui pengkajian buku-buku, jurnal, majalah, serta pendapat para ahli secara tidak langsung, yang kemudian akan dianalisis secara mendalam. Selain itu, penelitian ini menggunakan teknis analisis deskriptif, yaitu analisis dengan cara memaparkan data yang telah terkumpul dan tersusun secara sistematis. $^{13}$

Sumber diperoleh dari dokumen dan informasi beberapa temuan-temuan di berbagai jurnal dan hasil penelitian sebelumnya. Dokumen tersebut telah melalui tahapan-tahapan analisis dari berbagai keabsahan data atau sumber yang banyak dikaji oleh para peneliti, serta dianalisis dengan fakta bersifat obyektif melihat pengembangan pariwisata halal di Indonesia.

\section{KONSEP DASAR}

\section{Konsepsi Pariwisata Halal}

Ditinjau dari artinya, kata "wisatawan" yang berasal dari bahasa Sansekerta "wisata" yang berarti "perjalanan" yang sama atau dapat disamakan dengan kata "travel", dalam bahasa Indonesia memakai akhiran "wan" untuk menyatakan orang, jadi makna wisatawan adalah orang yang

\footnotetext{
${ }^{11}$ Suerjono Sukanto dan Sri Mamudji, Penelitian Hukum Normatif Suatu Tinjauan Singkat, Cet. 11 (Jakarta: PT. Raja Grafindo Persada, 2009), 13-14.

${ }^{12}$ Sugiyono, Metode Penelitian Kuantitatif, Kualitatif Dan R\&D (Bandung: Alfabeta, 2013), 224.

${ }^{13}$ Jalaludin Rahmat, Metodologi Hukum (Jakarta: Fajar Agung, 1997), 134.
}

sedang tidak bekerja, atau sedang berlibur dan secara sukarela mengunjungi daerah lain untuk mendapatkan sesuatu yang lain. ${ }^{14}$

Dari tinjauan arti wisata di atas, maka kajian tentang pariwisata halal banyak dikenal dalam beberapa istilah seperti, Islamic tourism, syari'ah tourism, halal travel, halal friendly tourism destination, Muslim-friendly travel destinations, halal lifestyle, dan lain-lain. Perbedaan atau hubungan istilah wisata dan pariwisata, karena di beberapa konsep ada yang menggunakan istilah wisata halal dan pariwisata halal dengan istilah bahasa inggris sama yaitu halal tourism. Secara umum istilah dalam bahasa arab hanya dikenal dengan menggunakan istilah siyāhah.

Istilah wisata diartikan perjalanan, dalam bahasa Inggris disebut dengan "Travel". Sedangkan pariwisata berasal dari bahasa Sansekerta, yakni “...pari yang berarti banyak, berkali-kali, berputar-putar, keliling, artinya bahwa pariwisata ialah perjalanan yang dilakukan dari satu tempat ke tempat lain, dalam bahasa Inggris disebut dengan "Tour". 15

Dalam bahasa Arab konsep pariwisata menggunakan istilah siyāhah, sedangkan dalam bahasa Inggris menggunakan istilah tourism. Secara bahasa, bahwa siyāhah dari kata "attajâ̂alū", seperti contoh: sāha fil 'ardhi" yang artinya pergi dan berjalan di atas muka bumi. Konsep lain, bahwa lafad siyāhah dari kata "adh-dharbu fil 'ardhi" yang artinya perjalanan di muka bumi seperti jalannya air. ${ }^{16}$ Selanjutnya, yang membedakan antara

${ }^{14}$ Dian Kusumaningrum, "Persepsi Wisatawan Nusantara terhadap Daya Tarik Wisata di Kota Palembang." Tesis (Yogyakarta: Universitas Gadjah Mada, 2009), 16-17.

${ }^{15}$ Koko Irawan, "Potensi Objek Wisata Air Terjun Serdang Sebagai Daya Tarik Wisata di Kabupaten Labuhan Batu Utara," dalam Kertas Karya (Sumatera Utara: Universitas Sumatra Utara Program Pendidikan Non Gelar Pariwisata, 2010), 11.

${ }^{16}$ Hamîdah Bū'mūsyah, “Daur al-Qitâa' alSiyâhi fî Tamwīli al-Iqtisâdi al-Watani Li Tahqìq al- 
islamic tourism dan secular tourism adalah tujuannya berwisata dalam Islam bukan semata karena ada masalah namun untuk menambah pengetahuan dan mengunjungi tempat yang menambah spirit keislaman.

Konsep siyāhah menurut Vaus schuller, Austria menyatakan yaitu setiap perjalanan yang masuk khususnya kerjakerja ekonomi yang berkaitan dengan masuknya unsur-unsur asing dan melanggengnya yang temporer dan terjadi penyebaran transaksi kedalam dan keluar wilayah tertentu. Terpusatnya pada sektor ekonomi terutama menuju pariwisata eksport dan import. $^{17}$

Siyāhah adalah perpindahan dari tempat ke tempat lain yang di luar lingkungan sang musafir untuk mencari relaksasi dan menghirup udara segar dan mencari tempat yang nyaman, indah pemandangannya, lama tidak dikunjunginya dan tidak ditunjukkan untuk kepentingan pokok diantaranya: berdagang, mencari untung atau mencari gaji dari sebuah pengabdian diri kepada Tuhan Sang Pencipta. ${ }^{18}$

Definisi halal menurut Al-Jurjani ahli bahasa Arab dalam kitāb at-Ta'rīfāt menunjukkan bahwa kata halal menyangkut kebolehan menggunakan benda-benda atau apa saja dibutuhkan untuk memenuhi keperluan fisik termasuk di dalamnya makanan, minuman, dan obat-obatan ${ }^{19}$.

Tanmiyah al-Mustadâmah (Dirâsah Halah alJazair)”, Tesis (Ttp: Jâmi’ah Farhāt ‘Abbâs, 2012), 17.

${ }^{17}$ Hamīd 'Abdūl Nabī al-Ṭai, Ushūlul Sinā 'ati Siyà̄hah (Urdūn: Al-wārîq Li Nașr al-Taujî, 2006), 23.

${ }^{18}$ Hudâil Muwaffiq Maḥmūd, Al-siyâhah wa Astathmâr Daur al-Marâqid al-Muqaddasah fi Tahqiq Tanmiyah 'Umrâniyah Mustadāmah (Madinah: Sâmirâ' Hâlah Dirâsiyâh, tth.), 3.

${ }^{19}$ Halal dari kata (halla, yahillu, hillan) $=$ membebaskan, melepaskan, memecahkan, membubarkan dan membolehkan. (1) segala sesuatu yang menyebabkan seseorang tidak dihukum jika menggunakannya; (2) sesuatu yang boleh dikerjakan menurut syarak. Lihat Abdul Azis Dahlan (Ed), Ensiklopedi Hukum Islam (Jakarta: Ichtiar Baru van Hoeve, 1996), 506.
Konsep halal tidak hanya diaplikasikan pada makanan, tapi itu termasuk syariah produk compliant mulai dari urusan bank hingga kosmetik, vaksin dan pariwisata. Ini berarti menawarkan paket wisata dan destinasi yang didesain khusus untuk memenuhi pertimbangan muslim dan menangani kebutuhan muslim. $^{20}$

Dalam penggunaan halal dalam alQur'an adalah sama dengan thayyib, yang memiliki makna bersih dan halal. Thayyib adalah kata sifat yang pada dasarnya menunjukkan kualitas produk yang baik. Thayyib juga digunakan untuk merujuk pada ucapan sebagai sebuah ucapan yang menyenangkan bagi siapapun. ${ }^{21}$

\section{Konsepsi Etika Bisnis Islam}

Ajaran yang terpenting dalam Islam yang pertama yakni melaksanakan moral dan elemen etis mencurahkan diri pada Allah. Hal ini mendefinisikan etika dan moral dari perspektif Islam sebagai akhlaq atau keadaan perasaan yang membentuk tingkah laku manusia. Banyak ajaran dan contoh etika di dalam al-Qur'an, hal ini sebagaimana bentuk sumber ekspresi ideal secara tradisi berdasarkan pepatah dan perbuatan nabi Muhammad SAW. ${ }^{22}$

Sistem etika Islam bersumber dari ajaran yang universal yakni al-Qur'an dan al-Hadits. Tujuan utama ajaran Islam tidak hanya mengedepankan nilai-nilai materialistis. Etika yang dibawa oleh Islam ialah konsep manusia untuk hidup yang baik dan menekankan persaudaraan, sosialekonomi, keadilan, kebutuhan kepuasan

${ }^{20}$ Oraphan Chanin, P. Sriprasert, H. Abd Rahman and M.S. Don, "Guidelines on Halal Tourism Management in the Andaman Sea Coast of Thailand", Journal of Economics: Business and Management, Vol.3, No. 8 (August, 2015): 791-794.

${ }^{21}$ Mohammad Hashim Kamali. "Tourism and the Halal Industry: A Global Shariah Perspective", The World Islamic Tourism Forum 2011, (July, 2011): 455-473.

${ }^{22}$ Mohammad Noorizzuddin Nooh, "Entrepreneurship, Ethics and Religiosity", Journal of Business and Economic Policy, Vol. 2, No. 4 (December, 2015): 175-178. 
yang seimbang dari keduanya dan nilai spiritual memenuhi kebutuhan semua manusia. $^{23}$

Etika merupakan ilmu tentang apa yang baik dan apa yang buruk dan ilmu tentang hak dan kewajiban moral (akhlak). Arti lain dengan filsafat tentang nilai-nilai, kesusilaan tentang baik dan buruk. ${ }^{24}$ Etika itu identik dengan istilah benar atau akhlak, maka ketika dipraktekkan bidang ekonomi sesungguhnya bisa dikatakan dengan akhlak ekonomi. Akhlak ekonomi bermuara pada akhlak ekonomi Islam. Seperti yang dikemukakan oleh Yusuf al-Qardhawi, ekonomi Islam dijuluki oleh ekonomi akhlak.

Etika dapat didefinisikan sebagai himpunan prinsip moral yang membedakan apa yang benar dari apa yang salah. Ini adalah bidang normatif karena ia menentukan apa yang harus dilakukan atau tidak dilakukan. Etika bisnis, kadangkadang disebut sebagai etika manajemen atau etika organisasi, hanya membatasi kerangka acuannya terhadap organisasi. ${ }^{25}$ Dalam kajian etika Islam, ada beberapa parameter kunci dari sistem etika Islami di antaranya sebagai berikut:

1. Tindakan dan keputusan dinilai beretika tergantung pada niat individu.

2. Niat baik yang diikuti oleh tindakan yang baik dianggap sebagai pembuktian dari iman.

3. Islam memungkinkan seseorang kebebasan untuk percaya dan bertindak sesuai keinginannya, namun tidak dengan mengorbankan akuntabilitas dan keadilan.

${ }^{23}$ Gillian Rice, "Islamic Ethics and the Implications for Business", Journal of Business Ethics, Vol. 18, Issue 4 (February, 1999): 345-358.

${ }^{24} \mathrm{M}$. Amin Suma, Menggali Akar Mengurai Serat Ekonomi dan Keuangan Islam (Jakarta: Kholam Publishing, 2008), 292.

${ }^{25}$ Rafik Issa Beekun, Islamic Business Ethics (Herndon: International Institute of Islamic Thought, 1997), 2.
4. Kepercayaan pada Allah memberi kebebasan kepada individu dengan kebebasan penuh dari apapun kecuali Allah. $^{26}$

5. Keputusan yang menguntungkan mayoritas atau minoritas semua kalangan.

6. Islam menggunakan pendekatan sistem terbuka terhadap etika, bukan sistem yang tertutup dan berorientasi pada diri sendiri, hal ini akan meninggalkan rasa egoisme pada manusia.

7. Keputusan etika didasarkan pada pemahaman dari al-Qur'an dan alHadits.

8. Berbeda dengan sistem etika yang dianut oleh banyak agama lain, Islam mendorong umat manusia untuk mengalami tazkiyah melalui partisipasi aktif dalam kehidupan ini. Dengan bersikap etika ditengah ujian dunia ini, umat Islam membuktikan nilai mereka kepada Allah. ${ }^{27}$

Untuk menjelaskan tentang etika bisnis Islam, maka makalah ini memaparkan pendekatan akioma etika. Menurut Syed Nawab Haider Naqvi mengatakan, bahwa aktivitas ekonomi saat ini sudah saatnya untuk memasukkan nilai-nilai etik atau seperangkat aksioma Islam, di dalamnya terdiri: Kesatuan (Unity), Keseimbangan dan Kesejajaran (Equilibrium), Kehendak Bebas (Free Will), dan Tanggungjawab (Responsibility). ${ }^{28}$ Sedangkan pendapat lain, menjadi lima aksioma kunci mengatur etika Islami: Kesatuan (Unity), Keseimbangan dan Kesejajaran (Equilibrium), Kehendak Bebas (Free Will),

\footnotetext{
${ }^{26}$ Rafik Issa Beekun, Islamic Business Ethics, 19.

${ }^{27}$ Rafik Issa Beekun, Islamic Business Ethics, 20.

${ }^{28}$ Syed Nawab Haidar Naqvi, Ethics and Economics an Islamic Synthesis, (London: The Islamic Foundation, 1981), 62.
} 
dan Tanggungjawab (Responsibility) dan Kebajikan (Benevolence). ${ }^{29}$

\section{PEMBAHASAN DAN DISKUSI}

\section{Peluang Pengembangan Pariwisata Halal}

Melihat perkembangan pariwisata di beberapa negara muslim menangkap potensi besar wisata halal dengan mendesain pasar tersebut untuk mendapatkan perhatian bagi wisatawan baik domestik maupun mancanegara. Masjid menjadi icon besar sebagai top halal destinasi. Perkembangan pengelolaan wisata halal di atas baik yang terjadi di negara muslim dan non-muslim, bahwa wisata halal telah menciptakan sebuah pasar tersendiri dalam dunia pariwisata dan dengan demikian dunia industri wisata menjadi kompetitif.

Pertumbuhan populasi muslim cepat dan stabil di seluruh dunia. Karena Islam adalah yang terbesar kedua agama dengan jumlah pengikut tetap meningkat, pertumbuhan populasi ini diperkirakan mencapai $25,13 \%$ pada tahun 2020 dan $33,14 \%$ pada tahun 2075. Menurut Pew Research, ada sekitar 1,6 miliar Muslim di seluruh dunia pada tahun 2010 dan angka ini diperkirakan mencapai 2,8 miliar pada 2050, yang kira-kira $30 \%$ dari total dunia populasi. $^{30}$

Jumlah kunjungan wisatawan mancanegara ke Indonesia Agustus 2017 naik 36,11 persen dibanding jumlah kunjungan pada Agustus 2016, yaitu dari 1,03 juta kunjungan menjadi 1,40 juta kunjungan. Begitu pula, jika dibandingkan dengan Juli 2017, jumlah kunjungan wisman pada Agustus 2017 mengalami kenaikan sebesar 1,79 persen. Secara kumulatif (Januari-Agustus) 2017, jumlah kunjungan wisatawan mancanegara ke Indonesia mencapai 9,25 juta kunjungan atau naik 25,68 persen dibandingkan dengan

\footnotetext{
${ }^{29}$ Rafik Issa Beekun, Islamic Business Ethics, 20-21.

${ }^{30}$ Kettani, "2010 world muslim population," Proceedings of the 8th Hawaii International Conference on Arts and Humanities, (January, 2010): $1-61$.
}

jumlah kunjungan wisman pada periode yang sama tahun sebelumnya yang berjumlah 7,36 juta kunjungan. ${ }^{31}$

Meski memiliki lima agama resmi dan ratusan kelompok etnis, Indonesia memiliki muslim terbesar populasi di dunia yang menyumbang $12,7 \%$ Muslim dunia. Menurut sebuah laporan baru-baru ini, kirakira 222 juta orang, atau $87 \%$ populasinya adalah muslim. Karena itu, Indonesia adalah yang terbaik negara potensial di Asia Tenggara yang memiliki kemampuan untuk mengarahkan fokus utama industri pariwisata ke arah arah pariwisata halal. ${ }^{32}$

Pada tahun 2007 disebutkan bahwa ada potensi yang sangat besar bagi pariwisata halal dari sisi ekonomi. Pariwisata sebagai sektor andalan yang harus didukung oleh semua sektor lain terutama yang terkait langsung dengan infrastruktur dan transportasi. Indonesia memiliki potensi menjadi muslim friendly tourism yang besar. Negara ini besar dikarenakan rumah ibadah banyak yang indah-indah, kultur budaya Islami, kekayaan alam yang luas, masyarakat timur yang dikenal dengan insan keramahtamahan, dan lainnya. ${ }^{33}$

Pariwisata halal dunia atau yang lebih dikenal dengan World Halal Tourism Award 2016 (WHTA) sebenarnya sudah bermula di tahun 2015 lalu. Event ini memberikan penghargaan yang diberikan kepada destinasi-destinasi halal. Di tahun 2015 itu Lombok (NTB) keluar sebagai salah satu pemenang wisata halal dari tiga kategori yang dimenangkan Indonesia. Satu penghargaan diraih Sofyan Hotel Betawi di Jakarta untuk kategori World Best Family Friendly Hotel. Dua penghargaan diraih

${ }^{31}$ Lihat https://www.bps.go.id. Diakses pada tanggal 19 Oktober 2018.

${ }^{32}$ Lee Shi Yan, N.A. Zahari, A.S. Ismail and N.M. Zain, "Halal Tourism: A New World For Tourism Industry," International Journal of Asian Social Science, Vol. 7, No. 8 (2017): 643-657.

${ }^{33}$ Muhammad Zainul Majdi. "Menghadirkan Atmosfer Tanah Suci Selama Ramadhan di NTB", Halal Lifestyle \& Bsiness, Vol. 09 (2017): 21-23. 
Pulau Lombok, Nusa Tenggara Barat untuk kategori World Best Halal Tourism Destination dan World Best Honeymoon Destination. Destinasi halal yang dimaksud adalah tujuan wisata yang lengkap dengan fasilitas halal, pariwisata ramah wisatawan muslim (moslem friendly tourism). Contoh kriteria yang harus ada pada destinasi halal adalah mudah ditemukannya masjid, tempat wudhu, hotel memiliki petunjuk arah kiblat, jam shalat, kitab suci, dan lain sebagainya. Ini adalah modal besar bagi Indonesia untuk terus mengembangkan wisata halal. ${ }^{34}$

Pada akhir 2016, Indonesia telah berkomitmen untuk mencapai yang paling akhir halal tujuan wisata dunia. Negara ini mendominasi World Halal Tourism Award 2016 dengan kemenangan 12 penghargaan dari total 16 kategori. Pemenang diumumkan pada acara pemberian penghargaan yang diadakan pada tanggal 7 Desember 2016 di Abu Dhabi, Uni Emirat Arab. Meninggalkan hanya 4 kategori lainnya dimana Indonesia tidak kirim nominasi apapun, Indonesia membawa pulang $75 \%$ dari semua penghargaan.

Indonesia mendapatkan kesempatan satu peringkat tahun 2017 menempati posisi ketiga sebagai tujuan wisata utama untuk pasar wisata muslim. Indeks tersebut mencangkup 130 destinasi wisata termasuk negera-negara non-OKI dan OKI. Kenaikan peringkat Indonesia ini terjadi dua tahun berturut-turut. $^{35}$ Penelitian GMTI ini menunjukkan pasar wisata dengan konsep family friendly akan terus tumbuh pesat dan nilai dari sektor tersebut diperkirakan akan tumbuh hingga mencapai US\$220 miliar pada tahun 2020 nanti, dan mencapai US\$ 300 miliar pada tahun $2026 .^{36}$

\footnotetext{
${ }^{34}$ Wonderfulllomboksumbawa, Peduli dengan Kemajuan Pariwisata Halal? Yuk Menangkan Indonesia pada WHTA 2016! dalam https://www.wonderfullomboksumbawa.com. Diakses 01 November 2018,

${ }^{35}$ Tazbir Abdullah,
Momentum Tren", 37.
${ }^{36}$ Tazbir Abdullah,
}

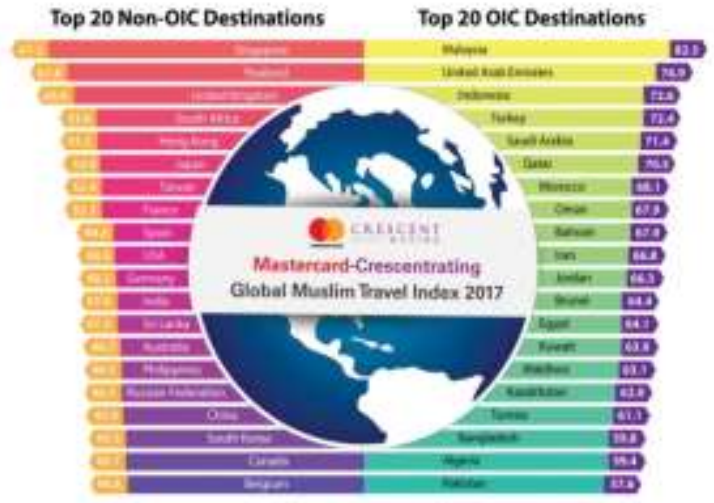

Sumber: Global Muslim Travel Index (GMTI) Mastercard-Crescent Rating 2017

\section{Etika Bisnis Islam dalam Pengembangan Pariwisata Halal}

Pariwisata halal adalah kegiatan perjalanan yang dilakukan oleh seseorang atau sekelompok orang dengan mengunjungi tempat tertentu untuk tujuan rekreasi, pengembangan pribadi, atau mempelajari keunikan daya tarik wisata yang dikunjungi dalam jangka waktu sementara. Pariwisata halal dilengkapi berbagai macam kegiatan wisata dan didukung berbagai fasilitas serta layanan yang disediakan oleh masyarakat, pengusaha, pemerintah, dan pemerintah daerah. ${ }^{37}$

Daerah tujuan pariwisata halal ialah kawasan geografis yang di dalamnya terdapat daya tarik wisata, fasilitas umum, fasilitas pariwisata, seperti keaslian (authenticity), keterjangkauan (affordability) dan aksesibilitas (accessibility) serta masyarakat yang saling terkait dan melengkapi terwujudnya kepariwisataan. Pengembangan pariwisata halal adalah kegiatan kunjungan wisata dengan destinasi dan industri pariwisata yang menyiapkan fasilitas produk, pelayanan, dan pengelolaan pariwisata yang memenuhi syariah. ${ }^{38}$

Penjabaran lima aksioma kunci mengatur etika Islami diantaranya: kesatuan, keseimbangan, kehendak bebas, tanggung

\footnotetext{
${ }^{37}$ Pasal 1 Perda Nusa Tenggara Barat No. 2 Tahun 2016 tentang Pariwisata Halal.

${ }^{38}$ Pasal 1 Perda Nusa Tenggara Barat No. 2 Tahun 2016 tentang Pariwisata Halal.
} 
jawab, dan kebajikan terhadap konsepsi wisata halal yang menitikberatkan pada tujuan pariwisata khususnya di Indonesia, hal ini dipaparkan sebegai berikut:

\section{Kesatuan (Unity)}

Pengertian etika Islam berasal dari iman dalam persatuan (tawheed) kepada Tuhan YME. Semua aksioma lain dari etika Islam dan prinsip teologi, ini semua berasal dari konsep Kesatuan (tawheed). Sistem etika Islam, yang mencakup kehidupan manusia di bumi secara keseluruhan yang bersifat kekal dalam konsep persatuan. Keyakinan mendasar bahwa "tidak ada Tuhan selain Allah SWT dan tidak ada satupun layak disembah kecuali Dia. ${ }^{39}$

Tauhid Islam bisa diartikan sebagai konsep pemujaan yang satu dan hanya Tuhan atau konsep monoteisme dan ini dianggap sebagai masalah moral. Dalam Islam yang pertama dan terutama penting moral dan elemen etis mencurahkan diri pada Allah. ${ }^{40}$ Dalam setiap aktivitas, seorang muslim senantiasa berlandaskan pada aqidah Islam. Tidak satupun terlepas darinya. Termasuk dalam hal ini adalah melakukan kegiatan ekonomi, setiap muslim harus senantiasa terikat padanya. Hal ini adalah merupakan konsekuensi dari keyakinan seorang muslim kepada Allah SWT.

$$
\text { Mengadakan perjalanan }
$$

terutama untuk berdagang atau berbisnis ke negeri tujuan dan dalam perjalanannya itu mereka mendapat jaminan keamanan dari penguasapenguasa dari negeri-negeri yang dilaluinya. Ini adalah suatu nikmat yang amat besar dari Tuhan mereka. Oleh karena itu sewajarnyalah mereka menyembah Allah SWT yang telah

${ }^{39}$ Jawed Akhtar Mohammed, "Social Responsibility of Businesses: A Philosophical Framework in Islam", Proceedings of the 8th London Business Research Conference, (July, 2013): 1-28.

${ }^{40} \mathrm{~S}$. Ahmed, Islam Basic Beliefs (Kuala Lumpur: A.S. Nordeen, 1999), 13. memberikan nikmat itu kepada mereka. Norma tentang wisata, seperti yang dikutip dalam Qur'an yakni surat alQuraisy (106): 1-4. ${ }^{41}$

Konsep pariwisata halal dapat diartikan bahwa kegiatan berwisata haruslah berlandaskan nilai ibadah dan dakwah di saat wisatawan muslim dapat mengambil rekreasi dan mensyukuri hasil pencipataan Allah SWT (tafakur alam / tadabbur alam). Allah SWT yang Maha Kuasa mengingatkan tentang ayat-ayat tentang perjalanan, sesuai dengan firman Allah SWT, dalam surat al-'Ankabut (29): $20 .{ }^{42}$

\footnotetext{
${ }^{41}$ Tafsir ayat ini, menjelaskan sejarah kebiasaan dilakukan oleh orang-orang Quraisy, (bepergian pada musim dingin) ke negeri Yaman (dan musim panas) ke negeri Syam dalam setiap tahunnya; mereka bepergian dengan tujuan untuk berniaga yang keuntungannya mereka gunakan untuk keperluan hidup mereka di Mekah dan untuk berkhidmat ke Baitullah yang merupakan kebanggaan mereka; (Maka hendaklah mereka menyembah) lafal ini menjadi ta'alluq atau tempat bergantung, (Yang telah memberi makanan kepada mereka untuk menghilangkan lapar) agar mereka tidak kelaparan (dan mengamankan mereka dari ketakutan) artinya supaya mereka tidak merasa takut lagi. Sesungguhnya mereka sering mengalami kelaparan, karena di Mekah tidak terdapat lahan pertanian, sebagaimana merekapun pernah dicekam oleh rasa takut, yaitu ketika tentara bergajah datang kepada mereka dengan maksud untuk menghancurkan Ka'bah. Lihat Jalaluddin AsySyuyuthi dan Jallaluddin Muhammad Ibn Ahmad AlMahalliy, Tafsir Jalalain. Pesantren Persatuan Islam 91 Tasikmalaya, versi 2.0 dalam http://myfaceonline.blogspot.com. Diakses 21 Oktober 2018.

${ }^{42}$ Tafsir ayat ini, menjelaskan (Katakanlah, "Berjalanlah kalian di muka bumi, maka perhatikanlah bagaimana Allah memulai penciptaanNya) yakni menciptakan orang0orang yang sebelum kalian, kemudian Dia mematikan mereka (lalu Allah menjadikan sekali lagi) dapat dibaca An Nasy-atal akhirata dan An Nasy-atal ukhra. (Sesungguhnya Allah Maha Kuasa atas segala sesuatu) antara lain ialah memulai dan mengulanginya. Pesantren Persatuan Islam 91 Tasikmalaya, versi 2.0 dalam http://myface-online.blogspot.com. Diakses 21
} Oktober 2018. 
2. Keadilan dan Kesejajaran (equilibrium) Secara filosofis dalam Islam adalah etika, karena etika membicarakan tentang keadilan. Kewajiban berbuat adil, ini memberikan informasi dan mengacu pada suatu kewajiban atau kebaikan yang berakar pada esensi secara rasionalisme dan tentunya berawal dari kehendak Tuhan yang dilaksanakan dengan ikhlas menjalankannya. ${ }^{43}$

Aksioma ekuilibrium ( $a l$ - $a d l)$ sesuai dengan konsep kesatuan aksiomatis. Selain dimensi vertikal aksioma persatuan (tawheed), kesetimbangan ( $a l$-'adl), yang dalam arti lebih dalam menunjukkan keseimbangan kekuatan, merupakan horizontal dimensi Islam. Karakterisasi dimensi Islam ini singkat dicatat, namun dalam konteks yang berbeda bahwa "ini adalah tujuan Islam gabungan rasa absolut dengan kualitas ekuilibrium". 44

Masalah etika yang paling fundamental atau esensial yang dihadapi bisnis adalah integritas dan kepercayaan. Pemahaman dasar tentang integritas mencakup gagasan untuk melakukan bisnis kegiatan dengan kejujuran dan komitmen untuk memperlakukan setiap pemangku kepentingan secara adil. Kapan pelanggan mengamati bahwa perusahaan mengungkapkan komitmen yang teguh terhadap etika praktik bisnis, tingkat kepercayaan yang tinggi dapat berkembang antara bisnis dan pelanggan itu berusaha untuk melayani. Sebuah hubungan kepercayaan antara bisnis dan stakeholder mungkin menjadi penentu utama kinerja

\footnotetext{
${ }^{43}$ Mohsen Javadi, "Model Epistemology in Muslim Ethics", Journal of Religious Thought: A Quarterly of Shiraz University, No. 11 (2004): 1-14.

${ }^{44}$ Mohsen Javadi, "Model Epistemology in Muslim Ethics", 1-14.
}

perusahaan. ${ }^{45}$ Pada akhirnya segala aktivitas di dunia bisnis, Islam mengharuskan untuk berbuat adil, tidak terkecuali pada pihak yang tidak disukai. Hal ini sesuai dengan firman Allah SWT, dalam surat al-Maidah (5) ayat $8 .{ }^{46}$

Pariwisata halal seyogyanya menerapkan nilai-nilai yang Islami di berbagai objek wisata, rumah makan, atau biro perjalanan. Selain itu, karakter jujur, amanah, bersih dan adil yang termasuk dalam kriteria halal, juga harus diterapkan di berbagai lini masyarakat kita yang menjadi daerah destinasi pariwisata.

Industri halal yang tepat adalah yang sudah bisa menjadi rahmatan lil 'alamin. Dengan berbagai contoh industri halal tidak diartikan dengan sempit. Industri halal mestinya bisa dinikmati pula oleh beragam orang tanpa memandang agamanya atau hanya dari orang Islam untuk orang Islam semata. Namun nilai keadilan dan produk berkualitas dari pariwisata halal bahwa orang non muslim juga merasakan dan tersentuh nilai kenyamanan, ketenangan dalam mencari keindahan alam yang disajikan. ${ }^{47}$

${ }^{45}$ Abdul Ghafar Ismail and Nor Azmidah Zali, "Ethics in Relation to Islamic Finance Activities", Islamic Research and Training Institute (IRTI) Working Paper Series, Issue 3 (April, 2014): 1-19.

${ }^{46}$ Tasir ayat ini maksudnya jadilah kalian sebagai penegak kebenaran karena Allah SWT., bukan karena manusia atau mencari popularitas. Dan jadilah kalian "saksi dengan adil", artinya secara adil dan bukan secara curang. Janganlah kebencian kepada suatu kaum menjadikan kalian berbuat tidak adil terhadap mereka, tetapi terapkanlah keadilan itu kepada setiap orang, baik itu teman maupun musuh kalian. Keadilan kalian itu lebih dekat kepada takwa daripada meninggalkannya. Lihat Abdullah Bin Muhammad Bin Abdurahman Bin Ishaq Al-Sheikh, Tafsir Ibnu Katsir, Juz 6 (Bogor: Pustaka Imam AsySyafi'i, 2004), 45-46.

${ }^{47}$ Utami Widowati, Non Muslimpun Tersentuh

Nilai Keadilan Ekonomi Syariah, dalam 
3. Kehendak Bebas (Free Will) / Ikhtiyar

Manusia diciptakan dengan satu konsep "kebebasan" seseorang, hanya Tuhan yang dapat sepenuhnya bebas, tapi tanpa melebihi atas rencana dan ciptaanNya. Manusia relatif lebih bebas dalam potensi yaitu mereka bebas memilih apa yang mereka mau kerjakan. Tetapi kehendak bebas yang diberikan Allah haruslah sejalan dengan prinsip dasar diciptakannya manusia dan harus sejalan dengan kepentingan individu terutama lagi kepada kepentingan umum. ${ }^{48}$

Kehendak Bebas (Ikhtiyar) adalah elemen yang dimiliki masingmasing individu, dan ini memberi manusia dengan kemampuan untuk membuat pilihan dalam situasi di mana mungkin ada isu-isu yang bertentangan terlibat. Makna lain kebebasan individu tidak dibatasi dan sukarela, untuk membuat pilihan dalam kepentingan individu terbaik dan tepat. Hal ini sesuai dengan firman Allah SWT dalam surat al-Israa' (17): $19 .{ }^{49}$

Teks tentang Ikhtiyar persamaan atau padanannya adalah usaha, pengertian lain yakni manusia sebagai individu dan kolektivitas mempunyai kebebasan untuk melakukan yang menurutnya positif guna mempertahankan atau aktivitas bisnis lainnya. Manusia yang baik dalam ketika menggunakan kebebasan dalam aktivitasnya selalu mengaplikasikan

https://halallifestyle.id/halal-news.Diakses Kamis, 19 Oktober 2018,

${ }^{48}$ Syed Nawab Haidar Naqvi, Ethics and Economics, 51-52.

${ }^{49}$ Tasir ayat ini maksudnya (Dan barangsiapa yang menghendaki kehidupan akhirat) yakni, menghendaki alam akhirat dan berbagai kenikmatan dan kebahagiaan yang ada disana. (Dan berusaha kearah itu dengan sungguh-sungguh) yakni, mencari hal itu melalui jalannya sedang ia mengikuti RasulNya, (Sedang ia adalah mukmin) yaitu, hatinya beriman, mempercayai adanya pahala dan balasan. Lihat Abdullah Bin Muhammad Bin Abdurahman Bin Ishaq Al-Sheikh, Tafsir Ibnu Katsir, Juz 15, 150. dengan kerangka tauhid dan keseimbangan yang berlandaskan pada aturan dari Allah SWT.

Pengembangan pariwisata halal yang mengedepankan dan menciptakan pertumbuhan perekonomian, menciptakan lapangan kerja, serta menghapus kemiskinan terhadap masyarakat di sekitar destinasi pariwisata. Sejalan dengan itu, inilah sebagai pilot projek yang harus menjadi prioritas utama pemerintah pusat maupun daerah untuk meningkatkan kesejahteraan masyarakat. ${ }^{50}$

Dengan usaha dan ikhtiar yang sudah maksimal akhirnya menunjukkan hasil yang signifikan yang berlahanlahan tapi pasti nilai-nilai yang memang terus diusung menjadi entitas pulau seribu masjid dan juga Islamic Center sebagai mercusuar pariwisata yang berbasis dan mengedepakan nilai-nilai agama dan budaya tersebut membuka mata dunia pariwisata internasional.

Dalam pengembangan pariwisata halal mendorong memberikan ide terkait pelaksanaan perencanaan, publikasi, program, dan destinasi wisata yang ada sehingga menambah nilai tambah yang dapat dijual tentang pariwisata halal. Oleh karena itu, rekonstruksi pariwisata syariah dalam bentuk pedoman pariwisata halal diperlukan untuk memperjelas pelaksanaan pariwisata halal sehingga kedepan akan berkembang lebih baik. Hal itu menjadikan pariwisata halal memiliki potensi besar untuk dikembangkan mengikuti permintaan pasar yang ada. Untuk itu pemerintah memoles sektor pariwisata sesuai standar internasional, mulai dari akomodasi, transportasi, makanan, dan destinasi yang ramah muslim.

\footnotetext{
Kepariwisataan.
}

${ }^{50}$ Pasal 3 dan 4 UU No.10 Tahun 2009 tentang 
4. Tanggung Jawab (Responsibility)

Dua aksioma (kehendak bebas dan tanggung jawab) bersatu sebagai sepasang menyeimbangkan satu sama lain. Konsep tanggung jawab memiliki dua unsur, yang pertama adalah status perwalian individu (al-'amin) bumi, dan yang kedua adalah aspek voluntaristik. Individu harus berusaha untuk mewujudkannya posisi menjadi khalifah Tuhan di bumi. Hal ini bertujuan melakukan sesuatu untuk meningkatkan kesejahteraan bagi masyarakat lainnya.

Terkait dengan kehendak kebebasan logis adalah aksioma batas uji tangung jawab. Untuk apa manusia bebas untuk melakukan dengan membuatnya bertanggung jawab atas semua yang dilakukan sesuai dengan firman Allah SWT, dalam surat alMudatstsir (74): $38 .{ }^{51}$ Kebebasan harus diimbangi dengan tanggung jawab jika hanya untuk memenuhi perintah dari equilibrium alam manusia, setelah memilih untuk kekuatan untuk memilih antara yang baik dan yang jahat harus bertahan konsekuensi logis.

Pariwisata halal pada dasarnya bukan kemudian mengubah destinasi wisata tapi memberikan pilihan bagi peminatnya agar mengakomodir nilainilai keyakinan mereka. Pariwisata halal bukan berarti menggerus atau membenturkan dengan pariwisata pada umumnya. Namun, tempat pariwisata tetap harus memberikan keindahan akan panorama sebuah destinasi, dan juga kenyamanan bagi para wisatawan. Fasilitas dalam pelayanan yang

\footnotetext{
${ }^{51}$ Tafsir ayat ini menjelaskan bahwa (tiap-tiap diri bertanggung jawab atas apa yang telah diperbuatnya) artinya dia tergadaikan, yaitu diazab di dalam neraka disebabkan amal perbuatannya sendiri. Lihat Jalaluddin Asy-Syuyuthi dan Jalaluddin Muhammad Ibn Ahmad Al-Mahalliy, Tafsir Jalalain. Pesantren Persatuan Islam 91 Tasikmalaya, versi 2.0 dalam http://myface-online.blogspot.com. Diakses 21 Oktober 2018.
}

memuaskan wisatawan ini yang kemudian harus diperhatikan, agar jika sektor wisatawan adalah muslim maka hak-hak kemuslimannya masih bisa terjaga melalui pelayanan fasilitas tempat shalat yang memadai, pemilihan jenis makanan dan minuman yang memberikan dampak bahwa apa yang mereka dapatkan terjamin berdasarkan struktur keyakinannya.

5. Kebajikan (Benevolence)

Berbuat kebajikan atau Ihsan adalah sebuah fitrah yang harus dilakukan guna mencapai keputusan dan tindakan sehingga menguntungkan manusia baik di dunia maupun di akhirat. Dalam konteks bisnis, ihsan menjadi sebuah nilai (value) kebaikan hati dan meletakkan bisnis pada tujuan berbuat kebaikan.

Dengan ihsan semua keputusan dan tindakan harus menguntungkan manusia baik di dunia maupun di akhirat, sesuai dengan firman Allah SWT, dalam surat Yunus (10): $59 .^{52}$ Selain hal itu seharusnya tidak dilakukan, Islam tidak membenarkan setiap tindakan yang dapat menimbulkan kerusakan terhadap diri, masyarakat, bahkan makhluk lain seperti binatang, tumbuhan, dan alam. ${ }^{53}$

Pariwisata halal adalah sebuah proses pengintegrasian nilai-nilai keislaman kedalam seluruh aspek kegiatan pariwisata. Nilai syariat Islam sebagai suatu kepercayaan dan

${ }^{52}$ Tafsir ayat ini yaitu ceritakanlah kepadaku tentang apa yang telah diciptakan oleh-Nya (berupa rezeki, lalu kalian jadikan sebagiannya haram dan sebagian yang lainnya halal), seperti ternak bahirah, ternak saibah dan bangkai. Tentang penghalalan dan pengharaman ini, tentu saja tidak (atau) bahkan kalian telah berdusta dengan mengaitkan hal tersebut dari Allah. Lihat Jalaluddin Asy-Syuyuthi dan Jallaluddin Muhammad Ibn Ahmad Al-Mahalliy, Tafsir Jalalain. Pesantren Persatuan Islam 91 Tasikmalaya, versi 2.0 dalam http://myfaceonline.blogspot.com. Diakses 21 Oktober 2018.

${ }^{53}$ Rafik Issa Beekun, Islamic Business Ethics, 21. 
keyakinan yang dianut umat muslim menjadi acuan dasar dalam membangun kegiatan pariwisata dengan mempertimbangkan nilai-nilai dasar umat muslim didalam penyajiannya mulai dari akomodasi, restaurant, hingga aktifitas wisata yang selalu mengacu kepada norma-norma keisalaman. Branding baru ini merefleksikan semangat bagi seluruh masyarakat yang disatukan melalui Syariat Islam yang rahmatan lil 'alamiin, sebagai cahaya benderang yang mengajak pada nilai-nilai kebaikan, kemakmuran, dan memberikan manfaat serta kebaikan bagi semua.

\section{KESIMPULAN}

Berdasarkan pemaparan di atas, dapat disimpulkan bahwa dalam bahasa Arab konsep pariwisata menggunakan istilah siyāhah, sedangkan dalam bahasa Inggris menggunakan istilah tourism. Secara bahasa, bahwa siyāhah dari kata "at-

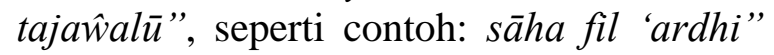
yang artinya pergi dan berjalan di atas muka bumi. Konsep lain, bahwa lafad siyāhah dari kata "adh-dharbu fil 'ardhi" yang artinya perjalanan di muka bumi seperti jalannya air.

Siyāhah adalah perpindahan dari tempat ke tempat lain yang di luar lingkungan sang musafir untuk mencari relaksasi dan menghirup udara segar dan mencari tempat yang nyaman, indah pemandangannya, lama tidak dikunjunginya dan tidak ditunjukkan untuk kepentingan pokok diantaranya: berdagang, mencari untung atau mencari gaji dari sebuah pengabdian diri kepada Tuhan Sang Pencipta.

Pariwisata halal adalah sebuah proses pengintegrasian nilai-nilai keislaman kedalam seluruh aspek kegiatan pariwisata. Nilai syariat Islam sebagai suatu kepercayaan dan keyakinan yang dianut umat muslim menjadi acuan dasar dalam membangun kegiatan pariwisata dengan mempertimbangkan nilai-nilai dasar umat muslim didalam penyajiannya mulai dari akomodasi, restaurant, hingga aktifitas wisata yang selalu mengacu kepada normanorma keislaman.

Menurut Syed Nawab Haider Naqvi dan rafik Isa Beekun mengatakan, bahwa aktivitas ekonomi saat ini sudah saatnya untuk memasukkan nilai-nilai etik menjadi lima aksioma kunci mengatur etika bisnis Islami didalamnya terdiri: Kesatuan (Unity), Keseimbangan dan Kesejajaran (Equilibrium), Kehendak Bebas (Free Will), dan Tanggungjawab (Responsibility) dan Kebajikan (Benevolence). Etika bisnis Islam dalam pengembangan pariwisata halal di Indonesia sudah dilakukan oleh pemerintah, pengusaha atau pengelola pariwisata atau juga masyarakat luas sebagai konsumen dan stakeholder lainnya.

Pemerintah segera membuat kerangka kerja peraturan dan kelembagaan yang tepat dan tepat yang terkait penyediaan lingkungan yang kondusif bagi industri halal, keterbatasan biaya anggaran pengembangan objek pariwisata nasional, kerusakan lingkungan akibat pengembangan yang tidak tepat, kurangnya sarana prasarana seperti toilet yang layak, tempat ibadah yang memadai, perlengkapan sholat dan sebagainya, jumlah akomodasi dan tempat makan yang tersertifikasi halal masih belum mencukupi permintaan pasar. Pemerintah baik dari tingkat pusat dan daerah mengembangkan secara sinergi dalam pengembangan pariwisata halal dan menyiapkan berbagai infratruktur penunjang yang didukung oleh seluruh stakeholder.

\section{DAFTAR PUSTAKA}

Abdullah, Tazbir. "Memanfaatkan Momentum Tren Pariwisata Halal". Halal lifestyle dan Business, Vol. 09 (2017).

Ahmed, S. Islam Basic Beliefs. Kuala Lumpur: A.S. Nordeen, 1999.

al-Ṣākhin, Sayyid Muhammad (ed). Fiqhul Siyāhah wa Safar, cet.1. Beirūt: Dār al-'Auliyâ', 2008. 
Al-Tai, Hamīd 'Abdūl Nabì. Ushūlul Sinā 'ati Siyāhah. Urdūn: Al-wārîq Li Naṣr al-Taujî, 2006.

Dahlan, Abdul Azis (Ed). Ensiklopedi Hukum Islam.Jakarta: Ichtiar Baru van Hoeve, 1996.

Firdausi, Izza, et.al. "Lombok: Halal Tourism as a New Indonesia Tourism Strategy". Paper presented at 4th International Conference on Humanities, Social Sciences and Education. Dubai: ttp., 2017.

Gillian Rice, "Islamic Ethics and the Implications for Business," Journal of Business Ethics, Vol. 18, Issue 4 (February, 1999).

Hamîdah Bū'mūsyah, "Daur al-Qitâ' alSiyâhi fî Tamwili al-Iqtisâdi alWatani Li Tahqīq al-Tanmiyah alMustadâmah (Dirâsah Halah alJazair)", Tesis. Jâmi'ah Farhāt 'Abbâs, 2012.

Hashimi, Sohail H. (Ed). Etika Politik Islam: Civil Society, Pluralisme, dan Konflik. Jakarta: ICIP, 2005.

http://www.indonesia.travel. Diakses pada tanggal 14 Oktober 2018.

https://halallifestyle.id/halal-news.

https://www.bps.go.id.

https://www.wonderfullomboksumbawa.com Irawan, Koko. "Potensi Objek Wisata Air Terjun Serdang Sebagai Daya Tarik Wisata di Kabupaten Labuhan Batu Utara" dalam Kertas Karya (Sumatera Utara: Universitas Sumatera Utara Program Pendidikan Non Gelar Pariwisata, 2010.

Ismail, Abdul Ghafar, and Nor Azmidah Zali, "Ethics in Relation to Islamic Finance Activities", Islamic Research and Training Institute (IRTI) Working Paper Series, Issue 3 (April, 2014).

Jaelani, Aan. "Halal Tourism Industry in Indonesia: Potential and Prospects", MPRA Paper No. 76235. Germany: University Library of Munich, 2017.

Javadi, Mohsen. "Model Epistemology in Muslim Ethics", Journal of Religious
Thought: A Quarterly of Shiraz. University, No. 11 (2004).

Kamali, Mohammad Hashim. "Tourism and the Halal Industry: A Global Shariah Perspective", The World Islamic Tourism Forum 2011, (July, 2011).

Kettani. "2010 world muslim population," Proceedings of the 8th Hawaii International Conference on Arts and Humanities, (January, 2010).

Kusumaningrum, Dian. "Persepsi Wisatawan Nusantara terhadap Daya Tarik Wisata di Kota Palembang", Tesis. Yogyakarta: Universitas Gadjah Mada, 2009.

Mahmūu, Hudâil Muwaffiq. Al-siyâhah wa Astathmâr Daur al-Marâqid alMuqaddasah fi Tahqiq Tanmiyah 'Umrâniyah Mustadāmah. Madinah: Sâmirâ' Hâlah Dirâsiyâh, tth.

Majdi, Muhammad Zainul. "Menghadirkan Atmosfer Tanah Suci Selama Ramadhan di NTB", Halal lifestyle \& business, Vol. 09 (2017).

Mohammed, Jawed Akhtar. "Social Responsibility of Businesses: A Philosophical Framework in Islam", Proceedings of the 8th London Business Research Conference, (July, 2013).

Naqvi, Syed Nawab Haidar. Ethics and Economics an Islamic Synthesis. London: The Islamic Foundation, 1981.

Nazir Moh. Metode Penelitian. Bandung: Ghalia Indonesia, 2003.

Nooh, Mohammad Noorizzuddin. "Entrepreneurship, Ethics and Religiosity", Journal of Business and Economic Policy, Vol. 2, No. 4 (December, 2015).

Oraphan Chanin, P. Sriprasert, H. Abd Rahman and M.S. Don, "Guidelines on Halal Tourism Management in the Andaman Sea Coast of Thailand", Journal of Economics: Business and Management, Vol.3, No. 8 (August, 2015). 
Perda Nusa Tenggara Barat No. 2 Tahun 2016 Tentang Pariwisata Halal.

Prodjo, Wahyu Adityo. "Cara Indonesia Menjadi Destinasi Wisata Halal Terbaik di Indonesia", Kompas.com, diakses pada tanggal 04 Oktober 2018.

Rafik Issa Beekun, Islamic Business Ethics. Herndon: International Institute of Islamic Thought, 1997.

Rahmat, Jalaludin. Metodologi Hukum. Jakarta: Fajar Agung, 1997.

Sugiyono. Metode Penelitian Kuantitatif, Kualitatif Dan $R \& D$. Bandung: Alfabeta, 2013.

Sukanto, Suerjono dan Sri Mamudji, Penelitian Hukum Normatif Suatu Tinjauan Singkat, Cet. 11. Jakarta: PT. Raja Grafindo Persada, 2009.

Suma, M. Amin. Menggali Akar Mengurai Serat Ekonomi dan Keuangan Islam. Jakarta: Kholam Publishing, 2008.

Susamto, Akhmad Akbar. Halal Industry as a New Source of Economic Growth. Jakarta: The International Seminar Seizing Golden Opportunity of Global Halal Business, 2017.

UU No. 10 Tahun 2009 tentang Kepariwisataan.

Yan, Lee Shi, N.A. Zahari, A.S. Ismail and N.M. Zain. "Halal Tourism: A New World For Tourism Industry," International Journal of Asian Social Science, Vol. 7, No. 8 (2017).

Zulkifli, Wan Sahida Wan, S.A Rahman, K.W. Awang and Y.B. Che Man, "Developing the Framework for Halal Friendly Tourism in Malaysia," Medwell Journals: International Business Management 5, No. 6 (2011). 